\title{
BIG DATA AND TOURISM: OPPORTUNITIES AND APLICATIONS IN TOURISM DESTINATION MANAGEMENT
}

\author{
Alfredo Brito Aguiar a; \\ Andressa Szekut b;
}

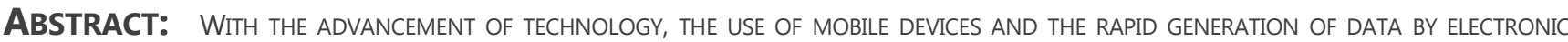
DEVICES, IT HAS BECOME INCREASINGLY STRATEGIC FOR MANAGERS TO USE TOOLS CAPABLE OF CAPTURING AND ANALYZING THE DATA GENERATED, IN ORDER TO TURN IT INTO USEFUL INFORMATION. THIS ARTICLE ADDRESSES A TOOL KNOWN AS BIG DATA FOR DATA ANALYSIS AND THE PROVISION OF RELEVANT INFORMATION THAT CAN CONTRIBUTE TO DECISION-MAKING BY AGENTS INVOLVED WITH THE TOURISM SECTOR. IT AIMS TO DEMONSTRATE THE APPLICATION OF THIS METHOD AND THE OPPORTUNITIES FOR DATA ANALYSIS USING BIG DATA, EXPLORING ASPECTS RELATED TO THE ADOPTION OF THIS TOOL. A QUALTATIVE DESCRIPTIVE RESEARCH WAS USED, WITH A LTTERATURE REVIEW AS THE MAIN DATA COLLECTION INSTRUMENT, FOCUSING ON THE USE OF ADVANCED TECHNOLOGIES. THE DATA WERE INTERPRETED IN LIGHT OF THE TECHNOLOGICAL AND COMPETTTIVE DEMANDS OF TOURISM SERVICES. THIS STUDY ADDRESSES SOME WAYS OF USING THIS TOOL, AND THE IMPORTANCE OF USING INNOVATIVE AND UP-TO-DATE TECHNIQUES TO UNDERSTAND THE TRENDS AND TRANSFORMATIONS IN TOURISM FLOWS AND IMPROVE THE CARE OF CONSUMERS IN THE GROWING TOURISM MARKET.

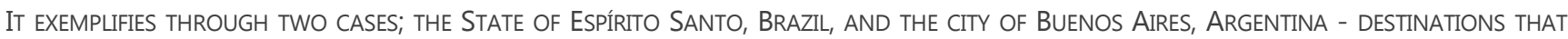
ALREADY USE BIG DATA TO ASSIST IN DECISION-MAKING.
\end{abstract}

\section{KEYWORDS}

Tourism

Big Data

Management 


\section{INTRODUCTION}

The tourism has expanded its actions in the international market in recent years, and now is one of the biggest economic sectors in the world. According to The World Travel \& Tourism Council - WTTC, in 2018, the tourism industry grew by $3.9 \%$, corresponding to $10.4 \%$ of the world's GDP, outperforming the global economic expansion (3.2\%) during the same period. In Brazil, the contribution of tourism to GDP increased by 3.1\%, generating 6.9 million jobs in 2018 . With this exponential growth, planning in the sector is essential for the development and competitiveness of tourist destinations that increasingly seek to stand out in the market.

To gain a better understanding of the transformations in the tourism sector, it is essential to carry out studies and analyses that support decision-making. However, with the technological advances, the high number of electronic devices connected on the internet, and rapid generation of data, it is necessary to use a tool capable of capturing, storing and interpreting the existing data and then providing useful in formation for policy-making that will optimize the industry.

In this context of a need for innovation for tourism planning, marked by the computer era, entities around the world are investing in technological innovations for large-scale data collection and analysis.

For example, the World Tourism Organization (UNWTO) signed a partnership in April 2019, with the Spanish telephone company Telefónica. Known for its contribution to meaningful information for country management, making data available through tools such as Big Data and Artificial Intelligence. The partnership between the UNWTO and Telefónica aims to stimulate digital investigation and entrepreneurship, the application of new technologies in the tourism sector, and especially, the development of a Digital Tourism Agenda to foster innovation and the development of destinations. (UNWTO, 2019).
In this article, we present a tool that enables information management to assist in efficient decisionmaking; Big Data. This tool is capable of collecting, storing and interpreting large volumes of data that cannot be handled by conventional software, and providing the results in a cost-efficient, rapid and flexible way, for public managers and private sector agents related to the tourism market. For a better understanding of this tool, we conducted a survey of the different ways in which it is applied in tourism.

It is hypothesized that this tool is used by public and private entities for the efficient management of data applied to tourism planning worldwide. We therefore sought to demonstrate the application of this tool, and the opportunities of using data analysis through Big Data, exploring relevant facts for its adoption in tourism. For this analysis, a descriptive qualitative study was used, with a literature review as the main data collection instrument, focusing on the use of advanced technologies. The data were interpreted in light of the technological and competitive demands of tourism services. We also conducted a survey of Internet pages of specialized entities that use this tool and provide data on the subject.

This article is divided into four section. The first section addresses theoretical and contextual questions about tourism and data analysis; the second focuses on the characteristics of Big Data; the third gives a survey of the use of Big Data in tourism; and finally, the fourth section outlines some experiences and perspectives on the use of this tool in the sector. The text therefore brings timely opportunities, and some of the contributions that data analysis by Big Data can provide for the management of tourist destinations. Two cases where this method is used are describd.

\section{TOURISM AND DATA ANALYSIS}

According to Mário Beni $(2003,7)$, although tourism is primarily a human and social science, its economic effects are prevalent, and it is a field that deserves careful study by researchers and entrepreneurs, especially using data and statistical analysis. Data published by 
the WTTC in 2018 demonstrate the economic importance of tourism, which corresponded to $8.2 \%$ of the Brazilian's GDP and $10.4 \%$ of the world's GDP.

The UNWTO World Tourism Barometer of January 2019 indicates an exponential growth in the tourism sector in recent years. It reports a $6 \%$ increase in international outbound tourism worldwide, compared to 2018, reaching 1.4 billion international arrivals worldwide. This is a milestone achieved two years ahead of the Tourism Towards 2030 - Global Overview, which forecasts 1.4 billion international arrivals worldwide by 2020 (UNWTO, 2010).

On the subject of tourism management and data use, Santos et al. state that: "The impacts generated by tourism activity are manifested basically at regional and local levels. Consequently, the management of resources, infrastructure and equipment must also be managed at these levels. Hence, the importance of monitoring tourism in destinations and creating policies that guide strategic actions based on consistent information" (Santos et al. 2018).

It is understood that the increasing importance of tourism in the market creates a need for tourism destinations to develop processes for collecting and disseminating information about the reality of tourism activity (Brandão; Costa, 2008). National and regional tourism management bodies should be equipped with tools to monitor tourism activity and provide timely and reliable information on its evolution, trends, dynamics and market position (Correia; Dinis; Milheiro, 2011).

Along with the need for information for decision making, it is observed that companies in the area have a lot of data, but these data are dispersed across various sources, making it difficult to analyze and use this information (Contreras; Franch, 2013). Over the years, national states and tourist destinations have sought to gather and organize this information. In Brazil for example, Embratur (the official Brazilian Tourism Institute) was created in 1966, together with the National Tourism Council, with the purposes of "supporting the formulation and coordinating the implementation of the National Tourism Policy, as a social and economic development factor".

Similarly, the Brazilian Ministry of Tourism was created in 2003, as a channel for dialogue with the states, to contribute to national tourism policies and elaborate strategic programs and projects for the sector (Ministry of Tourism. 2003). The first edition of the Ministry's National Tourism Plan was published in 2003, setting out guidelines and strategies for the implementation of the National Tourism Policy. The document is reviewed and rethought every four years, a the latest edition being published in 2018, with forecasts to 2022. The Ministry of Tourism is responsible, among other things, for collecting and analyzing national tourism data, including the largest tourism survey in the country - the international demand survey, which is carried out each year and made available on the Ministry's website, showing with different analyses on national destinations .

The UNWTO was initially created with the aim of standardizing the systematic collection and analysis of tourism sector data. It is the organization responsible for promoting responsible, sustainable and universally accessible tourism. It seeks to promote tourism as a driver of economic growth, inclusive development and environmental sustainability by providing advanced knowledge and policy support for the tourism industry worldwide. It was created in 1946 at The First International Congress of National Tourism Bodies as an international non-governmental organization, but in 2003, it joined the United Nations as The United Nation World Tourism Organization (UNWTO, 2018).

The UNWTO generates market knowledge, promotes competitive and sustainable tourism policies and instruments, fosters education, tourism training and works to make tourism an effective tool for development through technical assistance projects in over 100 countries around the world. It is also responsible for regulating tourism practices and studies. The UNWTO currently has 158 member nations, 6 associate members, and 500 affiliate members representing the private sector, educational institutions, tou- 
rism associations and local tourism authorities (UNWTO, 2018).

According to studies conducted by the World Tourism Organization, the data collected and stored must be strategically analyzed, for a better planning and management of tourism activity. This required creating favorable conditions for the data to be collected, analyzed and made available in a systematic way, by qualified professionals, using technologies that enable the information to be extracted.

To address this issue, in 1994 the United Nations Statistics Division developed its Recommendations for Tourism Statistics. Updated and revised by UNWTO in 2008, to become the International Recommendations for Tourism Statistics. This document that focuses on the tourists' activities, measuring them against monetary and non-monetary indicators. It is intended to provide a common reference framework that all countries can use to compile their tourism statistics. "The main objective is to present a system of definitions, concepts, classifications and indicators that are internally consistent and that facilitate the link to the conceptual frameworks of the Tourism Satellite Account national accounts, the balance of payments and labor statistics In addition, general guidance with respect to data sources and data compilation methods is also provided and will be complemented by a forthcoming compilation guide." (UNWTO, 2008).

Based on the different experiences of the Tourism Observatories around the world, some of which will be outlined during this article, it is clear that in order to list and define the data to be collected and analyzed by the observatories, a management is needed that is open to debate and that plans actions together with tourism agents. Broad participation is required, to generate information that serves the common interests. Each observatory should be responsible for providing information that meets the needs of its destination. However, certain data is considered essential knowledge for any manager.

Key areas of research for the generation of data include tourism supply and demand, visitor satisfaction, investment and finance opportunities, and tourism impacts. Identifying current and potential products and tourist itineraries is also important.

In 2004, the UNWTO created the International Network of Sustainable Tourism (INSTO), to support the continuous development of sustainability and resilience in the tourism sector through systematic, timely and regular monitoring of tourism performance and impact and to connect dedicated destinations in order to better understand destination-wide resource use and foster the responsible management of tourism. (INSTO, n.d.)

In 2019, this network consisted of 25 Tourism Observatories; Brazil is represented only by the São Paulo Tourism Observatory. Through the systematic application of monitoring, evaluation and information management techniques, INSTO provides to policy makers, planners and tourism managers with important tools to strengthen the institutional capacities of these actors involved (INSTO, n.d.).

With advances in technology, such as fast internet connections and the use of mobile devices, access to information has become easier, generating a much larger volume of data than in previous decades. According to a 2018 survey by technology Company Cisco, by 2022, the volume of IP traffic on global networks will exceed that of all Internet years together (between 1984 and 2016). The Cisco Visual Networking Index Report is based on analysis and actual data on the use of fixed and mobile data prepared by independent analysts.

In this context, new forms of data collection and analysis are emerging. One of the tools that contribute to the planning and elaboration of public policies is Big Data, which has the capacity to store and analyze large amounts of data, allowing a better understanding of the analyzed sector. This phenomenon means that the sheer volume of heterogeneous data produced every second of the day is unquestionably becoming the new bridge to growth and innovation. (Karampatsou, 2018). The tool offers significant advantages, such as more efficient decision making, collabo- 
rating with improved planning, and fostering the systematic growth of tourism activity.

Understanding the importance of tourism in the international market, and the need for data management for better activity planning, associated with the speed and volume of information generation, we shall now present this tool in more detail.

\section{BIG DATA}

Big Data refers to all data sets where the size is larger than the ability to search, capture, store, manage, analyze, transfer, view, or legally protect conventional computer tools. It also includes infrastructures, solutions, and necessary models to extract value from these information groups as economically, quickly, and flexibly as possible for smart decision making. (Invat.tur, 2015).

Doug Laney, in 2001, was the first to define three important characteristics for data planning and analysis: volume, velocity and variety. - which would be later come to known as "The 3Vs of Big Data".

Volume: the amount of data available on networks that can be used for analysis. Studies indicate that the mobile data traffic will grow at a Compound Annual Growth Rate (CAGR) of 46\% from 2017 to 2022, reaching 77.5 exabytes per month by 2022 (CISCO, 2019).

Velocity: how quickly data is created, stored and processed. This growing rate of data requires companies to process information in real time, or near real time, for quick decision making (Minelli et al. 2013).

Variety: the diversity of generation sources and data formats. From messages, updates, photos and videos that are made available on social networks, to GPS. It consists of structured data (tables and records), unstructured data (text and voice records), and semistructured data, which is difficult to classify as its derived from audio, video and other media (Vassakis et al. 2018, p. 5).
In 2005 Roger Mougalas, director of market research at O'Reilly Media, used the term "Big Data" for the first time, defining it as a wide range of data that is almost impossible to process using traditional data management tools, due to its size and complexity (Karampatsou, 2018).

Since then, researchers have added four more "V's" to the definition: veracity (the accuracy and confidence level of these data), variability (constant transformation of the data), visualization (effective and visual use and analysis of the data) and value (the data can generate high information value for the development of some sector) (Karampatsou, 2018).

Because it represents a vast amount of data involuntarily generated every second, the United Nations Economic Commission for Europe (2013) indicates that Big Data has several collection sources, which are divided into three categories: Social Networks (online platforms where people share experiences and photos and exchange messages); Business Systems (the record of all procedures performed in a company, monitoring and operationalizing actions within the organization); and the Internet of Things (sensors in electronic devices that record and measure situations around you, such as weather, traffic, and GPS).

However, Big Data in its raw form has no real value, as it is simply numerous heterogeneous data spread across the internet. So, to provide real information requires processing and analysis. Thanks to advanced software, it is possible to move from descriptive analysis, which is the examination of data or content, usually performed manually, to answer the question "What happened?" (Or "what is happening?"); for a prescriptive analysis, a form of advanced analysis that examines data or content to answer the question "What will happen?" or "How can we make this happen?" As described in FIGURE 1. 
Figure 1: Policy analytics ladder.

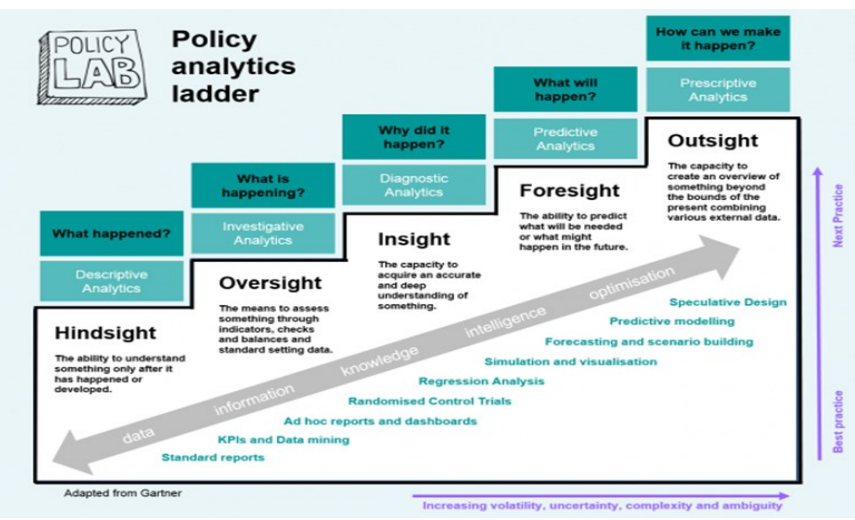

Source: Siodmok, 2017

It is important to point out that software that uses Big Data can quickly interpret large volumes and varied forms of data, but in order to achieve effective results from the use of this tool, the presence of professionals is needed, who are able to operate and analyze the information generated and know how to ask the right questions. Combining technology with managers' perceptions, the authors indicate that it is possible to make diagnoses that help the development of the tourism sector and decision making.

\section{BIG DATA AND TOURISM}

The main characteristics of tourism are mobility, flow, and intangibility. Therefore, the collection of sector data has always been a complex problem. Big Data is an innovation that can bring benefits that go beyond the results of other research and data collection, precisely because of the mobility and speed at which tourist activity occurs, and the possibility of real-time analysis afforded by Big Data. The economic impact of Big Data is hard to estimate, especially in a global environment with permanent technological revolution. One of the benefits of the large amount of data is its potential to predict and anticipate behaviors, expectations and needs of a specific group of consumers, making analysis processes smarter and safer, and decisions more efficient and cheaper. (Invat.tur, 2015). Based on the different experiences analyzed, Big Data brings significant contributions to the tourism sector:

Identifying trends and behaviors: Big Data enables managers to find behavioral patterns and establish consumer trends that are practically impossible to detect using traditional methods and techniques. This advantage fosters the development of specific market segments and study, by collecting and integrating data from multiple sources (Invat.tur, 2015).

\section{Knowledge of demand and customizing products} and services: to provide the tourist with the most appropriate solution, based on their needs, Big Data looks at consumer behavior. As a source of information, the consumers' interests, preferences, group affiliation, academic and professional background and even geographical location can be observed through the client's profile on social networks. (Habegger B., 2014). The importance of personalization of tourism services is constantly growing; The modern traveler is attracted to flexible and updated services, with visitor appreciation and the ability to meet their needs being considered the most important prerequisites for customer loyalty. (Karampatsou, 2018). For example, a tool called "Custom Audience" allows companies to target their ads to customers with content they are interested in, without overwhelming them with unwanted information. (Karampatsou, 2018).

Development of new products and services: Another important benefit of Big Data is its role in delivering new and competitive products and services. Through predictive and prescriptive analytics, companies can now gain insight into markets and find unique and creative ways to respond quickly to emerging opportunities. (Sivarajah U., 2016). Innovative online travel companies like Amadeus have already implemented Big Data into their business strategies, to refine their products and differentiate themselves from their competitors. The company uses this information to design and implement innovative tools, such as "Amadeus Extreme Search," which allows travelers to enter preferences such as budget, destination activities, geography, to provide recommendations for potential destinations that meet travelers' preferences on its website (Amadeus, n.d).

Decision-making agility: By combining Big Data with Artificial Intelligence, it is possible to analyze a situation 
in real time and automatically modify prices, services, and advertisements according to demand and interactions across distribution channels. For this, it relies on much more understandable visual models: heat maps, scatter plots, 3D visualizations, word clouds, among others (Invat.tur, 2015).

Optimizing processes and internal operations: Business managers employ Big Data as a powerful tool to streamline decisions that lead to an improved, customer-focused approach (Karampatsou, 2018). Airlines use these analyzes for routing, crew scheduling and logistical maintenance decisions. Hotels use the data for power system management. Other companies, for example, try to match personality characteristics of frontline employees with the task performed (selling) or the inferred or observed attributes of customers (difficult or annoyed). As tourism is a service-oriented sector, these types of analytical interventions are likely to improve service levels and customer satisfaction (Davenport, 2013).

Revenue Management: This is the process by which a company sets the ideal price for its products and services, making them more attractive to potential customers. Using Big Data, companies can effectively ensure consistent price optimization with analytical models and algorithms that track and analyze competitor prices, enabling them to build a competitive pricing strategy and better revenue management capabilities (Karampatsou, 2018).

Thereby, Big Data can be used in different ways for data management and tourism planning. We therefore sought to study examples of the use of this tool applied to tourist destinations in Brazil and worldwide. These are outlined below.

\section{EXPERIENCES AND PROSPECTS}

In this part of the text, to address historical data on the use of research methods and data analysis by official tourism institutions, a survey was carried out of the institutions' websites and official documents made available on the web pages. The institutions most fre- quently used for this purpose were the World Tourism Organization and the Brazilian Ministry of Tourism.

For the case studies of destinations that already use Big Data to analyze and manage their data, information was collected through publications and documents on the official websites of the destinations, namely, the websites of the Tourism Observatory of Buenos Aires, Argentina, and the Tourism Observatory of the State of Espírito Santo, Brazil. In addition to the websites, official documents related to the methodological description of the Big Data survey used in these locations were also consulted, to gather information about the application of Big Data in each location.

According to the analysis, Big Data proved to be an important tool for decision making of tourist destinations in recent years. Spain, a pioneer in this area, uses telephony data to analyze tourism flows, and has several planning agencies that use Big Data to think about its country management and the tourism sector.

In Argentina, the Buenos Aires Tourism Observatory with the objective of generating market intelligence and guiding decision-making among public sector, companies and industry professionals and enhance tourism as a strategic activity for economic and social development of the city - began to invest in buying telephony data and Big Data analysis techniques. This investment gave rise to the Tourism Intelligence System, which was publicly presented in April 2019. According to INSTO n.d. data, through this initiative, Buenos Aires became the first city in South America to develop its own Big Data tool applied to tourism.

The Buenos Aires Tourist Intelligence System is considered a new tool that integrates multiple sources of information through collaboration with public and private organizations such as the Secretariat of Tourism, the global distribution system Amadeus, Telefónica and the Aeropuertos Argentina 2000 network (Ciudad De Buenos Aires, 2019).

According to the observatory's website, through this tool, the platform provides data such as: prospective 
information to anticipate the behavior of tourism demand from searches and air reservations to Buenos Aires from around the world; tourist mobility in the city's neighborhoods; the main areas of attraction and flow of national and international tourists by weekdays and months of the year; hotel competitiveness, with data on hotel occupancy rates, room rates, and comparisons with other destinations in the region, and; characteristics of international tourism, such as arrival, origin, length of stay and international tourist spending. This data is made available in a simple and practical way with dynamic and interactive charts on the observatory web page (as exemplified in FIGURE 2). And they contribute to decision making in public and private bodies.

Figure 2: Tourist mobility through the neighborhoods of Buenos Aires.

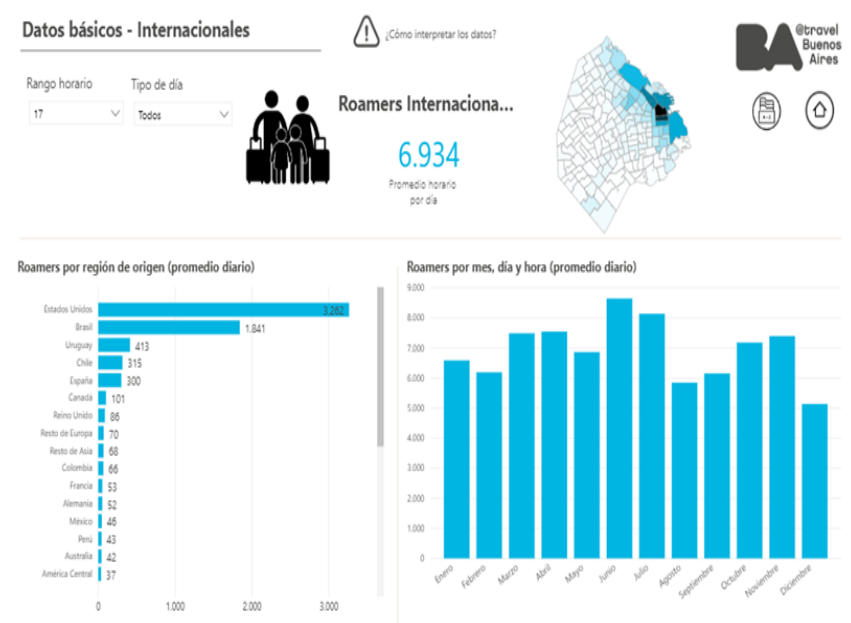

Source: Ciudad de Buenos Aires, 2019.

Since it first began to be used by public agencies, the Tourism Intelligence System has already contributed with some strategic management initiatives such as: promoting the tax incentive legislation for the hotel sector (Ciudad De Buenos Aires, 2018), to boost the construction and remodeling of accommodation facilities; studying potential demand, to drive new air connectivity; redefining and segmenting digital communication and marketing strategies, identifying new markets and strengthening actions with current markets; improving visitors' experience in the city of Buenos Aires in different neighborhoods and also at different times of the year; interacting with other areas of gover- nment to enhance overall destination management by defining security, transportation and public space strategies and; improving the measurement of tourist turnout at gastronomic, sporting and cultural events (Ciudad De Buenos Aires, 2019).

Data from the Tourism Intelligence System was made publicly available in April 2019, and the Buenos Aires Tourism Observatory believes that this tool will improve the quality of decision making for hotels, travel agencies, airlines and tourism entrepreneurs in the region. (Ciudad De Buenos Aires, 2019)

A Brazilian example of the use of Big Data is the State of Espírito Santo, where the Tourism Observatory began to invest in Big Data technologies in a partnership between the State Secretariat of Tourism, Telefônica Vivo Business Solutions and Luca Data-Drive Decisions. In order to implement demand and tourism flow research through mobile phone signal in the state; study tourism demand and determine direct or indirect impacts on the economy to assist in the planning and development of new tourism products; and determine tourist characteristics to enable the formulation of promotional and marketing strategies (SETUR-ES. 2017).

Prior to the research, a Methodological Descriptive was carried out in 2017, to identify the objectives of the research and its legal aspects, both in terms of confidentiality and the process of filtering user profiles for data collection.

Through mobile signals, it is possible to identify statistical data on visitor's movement, location and length of stay at attractions. Data is captured 24 hours a day through more than 3,000 mobile phone signal antennas from Vivo DATA S.A. The survey was applied at specific times and during events in the state in 2016 and 2017, such as extended carnival holidays, summer season and July holidays. (SETUR-ES. 2017).

As these two examples of using the Big Data tool show, telephone companies are references for tourism data collection and analysis, precisely because of their flow mapping capabilities, and mobility. Each data source 
has specific indicators that can be surveyed and analyzed individually or in cross-reference with other data. For example, credit card data can be used to estimate visitor spend at destinations, in different time periods and areas, broken down by nationality, and so on.

It is important to emphasize that data capture needs to be linked to a previously elaborated question, to ensure an analysis that is useful for public and private sector planning. Because the volume of data is immeasurable and heterogeneous, and because many different questions can be answered by different sources, a lack of clearly-defined question can lead to high spending without any return for investors. Thus, using a database depends not only on having equipment and technology available, but also on a multidisciplinary team of professionals who think globally about the extraction, analysis and use of such data.

These are just two examples, but it was noticed that the use of this tool, for analysis of different factors of tourist activity, has become popular around the world. The UNWTO, in a partnership relating to large-scale data usage with Telefónica and with Google, shows that industry data surveys are moving towards this methodology. The Sociedad Digital en España 2018, is a document which shows that destinations such as the Majorca Islands, the Balearic Islands and the Galicia region follow and invest in this trend. These examples demonstrate that this is an opportunity to achieve a large -volume real-time analysis of data that can be directly applied to tourism planning.

According to the contributions of Big Data outlined above, and the practical applications of the tool identified in Buenos Aires and Espírito Santo, it can be seen that the benefits and uses are mostly related to identifying trends and gathering knowledge of demand and tourist flows in each destination, enabling more rapid decision-making that is useful in the planning and competitiveness of destinations.

\section{RESULTS}

This article raises some of the contributions that Big Data and Artificial Intelligence can provide, based on the demand of each destination and the need to seek innovative means of decision making. The UNWTO points out that tourist destinations have difficulty adapting to the technological revolution, for reasons such as:

-The need to review and update outdated legislation and regulation that supports employment, innovation, entrepreneurship and new business models.

- The low level of awareness and expertise of new technologies and technological trends.

-A lack of funding to invest in new technologies and training for the jobs needed for the present and future.

-The lack of cooperation and communication among relevant stakeholders (UNWTO, 2019).

Due to these difficulties, the use of Big Data is still limited, albeit expanding. However, based on the content presented here, we can see the scope of Big Data, its benefits and usability, and begin to reflect on how it can be applied in a basic and direct way, to a particular destination or tourism company. Big Data is flexible; when a particular need arises, it can be adapted to perform the necessary analyses and achieve positive results.

With research and studies are conducted to understand the tourist flows of a destination, the manager can develop public policies and incentives to improve local infrastructure and visitors' experience in a unique and differentiated way. With Big Data, this can be done very quickly. In our example of Buenos Aires, using Big Data it was possible to promote tax incentive legislation for the hotel sector to promote the construction and remodeling of accommodation facilities; and the Spanish government has invested in Big Data technology to resolve the air traffic problem, using predictive data analysis models that can anticipate potential problems and generate automatic solutions. 
The increase of studies focused on technological advances, and the improvement of traditional data interpretation techniques in the information age, brings greater knowledge for investors and scientific researchers in the tourism sector. It favors the construction of relevant data generation and organization systems to develop new ways to solve problems and increase productivity.

Thus, the use of technologies like Big Data is directly linked to the concept of intelligent destination, which is understood as: an innovative tourism destination, consolidated in a cutting-edge technology infrastructure, which ensures sustainable development of the territory that is accessible to all, facilitates the interaction and integration of the visitor with the environment, enhances the quality of their experience at the destination, and improves the quality of life for resident. Through proper management, this tool enables integral planning of tourism activity.

\section{FINAL CONSIDERATIONS}

Tourism is an economic sector that is growing steadily, therefore research and analysis of the data generated is important for its management. Due to this demand, organizations such as Embratur and the Ministry of Tourism at national level, and the World Tourism Organization at international level, have developed official documents with systematic methods of collecting and interpreting tourism statistical data, to enable the comparison and use of compelling information to support the management and planning of the activity.

With the digital age and the vast amount of information generated by electronic devices and the internet, the search for understanding virtual reality and consumer behavior on social networks have become essential elements for decision making in any commercial market. Software was therefore developed that is capable of analyzing and clarifying people's needs.

Big Data, one of the methods used to analyze large amounts of data, has gained recognition in several are- as, such as health, education, sports and tourism. Although still little known and with low engagement by managers, it has proven to be a very useful tool in the management of tourist destinations around the world.

In tourism, Big Data can be used in all segments, including hotels, travel agencies, transportation and especially, private investment and promotion of public policies. Through the information provided by Big Data, tourism management agencies can identify trends and demand behaviors; develop and deliver innovative and personalized products and services; make decisions quickly; optimize internal processes and operations and; manage revenue in order to lower costs and increase customer satisfaction.

Cases such as the city of Buenos Aires and the state of Espírito Santo are already consolidated destinations in the tourism sector that use Big Data to improve public and private management through the available data. These two cases have already seen the benefits of using Big Data as a research and analysis tool to provide relevant information for tourism development.

Based on the above, Big Data is already a method of analysis used by some public and private entities for planning national and international tourism activity. It is necessary to search for innovation and to study new ways of adapting to the transformations and competitiveness of the tourist market. Through Tourism Observatories or private actions that use tools that provide concrete information to offer tourists differentiated and quality services, and to promote the development of tourist destinations. There is also a need for further studies on the subject, to increase our understanding of

\section{REFERENCES}

Amadeus Extreme Search. (n.d.). Retrieved from https:// amadeus.com/pt/portfolio/agencias-de-viagens-devarejo/amadeus-extreme-search

Aprobación de la ley de incentivos fiscales para el sector hotelero. (n.d.) Retrieved from https://www.buenosaires.gob.ar/ noticias/aprueban-la-ley-de-incentivos-fiscales-para-elsector-hotelero

Beni, M. C. (2003). Como Certificar o Turismo Sustentável? Revista Turismo em Análise, 14(2), 5-16. 
Brandão, F. \& Costa, C. (2008). Novas dinâmicas e novas formas de gestão para o sector do turismo ao nível local: o caso da criação de Observatórios Regionais de Turismo. In: CAVACO, C. (ed.) Turismo, Inovação e Desenvolvimento Actas do I Seminário Turismo e Planeamento do Território. Lisboa: Centro de Estudos Geográficos, Universidade de Lisboa, 255-280.

Brasil. Ministério do Turismo. (2003). Plano Nacional de Turismo: Diretrizes, Metas e Programas 2003-2007. 12. Retrieved from http://www.turismo.gov.br/siten.d.efault/turismo/ o_ministerio/publicacoen.d.ownloads_publicacoes/ plano nacional turismo_2003_2007.pdf

Brasil. Ministério do Turismo. (2018). Plano Nacional de Turismo 2018-2022. Brasília, 15. Retrieved from https:// cultura.rs.gov.br/upload/arquivos/ carga20180322/28162245-pnt-2018-2022.pdf

Brasil. Secretaria de Turismo do Estado do Espírito Santo. (2017). Pesquisa de Fluxo Turístico por Big Data - Descritivo Metodológico. Retrieved from https:// observatoriodoturismo.es.gov.br/descritivometodologico

Cardamone, R. (2016, May 25). A cidade e o futuro: como as cidades mais inteligentes vão transformar a vida da população. COMURB. Sociedade de Projetos Urbanísticos Ltda. Retrieved from https://comurb.com.br/a-cidade-e-ofuturo-como-cidades-mais-inteligentes-vao-transformar-a -vida-da-populacao/

CISCO. (2019, February 18) Visual Networking Index: Global Mobile Data Traffic Forecast Update, 2017-2022 White Paper. Retrieved from https://www.cisco.com/c/en/us/ solutions/collateral/service-provider/visual-networkingindex-vni/white-paper-c11-738429.html

Contreras, T. C.; Franch, D. B. (2013) Observatorio en turismo: organismo inteligente para la toma de decisiones en el destino. Revista Iberoamericana de Turismo - RITUR, 3(2), 25-34.

Correia, E.; Dinis, G.; Milheiro, E. (2011). Strategic Tools for Decision Support: The Regional Tourism Observatory of Alentejo. Book Of Proceedings - International Conference On Tourism \& Management Studies, 1(1), 143-150.

Davenport, T. H. (2013). At the Big Data Crossroads: turning towards a smarter travel experience. Amadeus IT Group. Retrieved from http://amadeusblog.com/wp-content/ uploads/Amadeus-Big-Data-Report.pdf

Habegger, B., Hasan, O., Brunie, L., Bennani, N., Kosch, H., Damiani, E. (2014). Personalization vs. Privacy in Big Data Analysis. International Journal of Big Data, 25-35.

INVAT.TUR. (2015). Big Data: retos y oportunidades para el turismo. Retrieved from https://www.ithotelero.com/ portfolio-item/big-data-retos-y-oportunidades-para-elturismo/

Minelli, M.; Chambers, M.; Dhiraj, A. (2013). Big Data Big Analytics: Emerging Business Intelligence and Analytic trends for today's businesses. (1st ed.) Hoboken, New Jersey: John Wiley and Sons Inc.
Observatório Turístico. (n.d.) Retrieved from https:// turismo.buenosaires.gob.ar/es/observatorio

OMT. (2000). Basic Concepts of The Tourism Satellite Account (TSA). Retrieved from http://statistics.unwto.org/sites/all/ filen.d.ocpdf/concepts.pdf

OMT. (2008). International Recommendations for Tourism Statistics 2008. Department of Economic and Social Affairs, 83 (1)

OMT. (2011). Tourism Towards 2030 / Global Overview. UNWTO 19th General Assembly.

OMT. (2018). About UNWTO. Retrieved from http:// cf.cdn.unwto.org/sites/all/filen.d.ocpdf/ aboutunwtojan2018web.pdf

OMT. (2019). World Tourism Day 2019 Technical Note. Retrieved from http://cf.cdn.unwto.org/sites/all/files/ world_tourism_day_2019_technical_note.pdf

OMT. (2019, January). World Tourism Barometer. World Tourism Organization. 17 (1)

OMT. (n.d). UNWTO/WTCF City Tourism Performance Research Report for Case Study: "Buenos Aires, Argentina". Retrieved from http://cf.cdn.unwto.org/sites/all/filen.d.ocpdf/ buenosairescasestudy.pdf

Presentación del Sistema de Inteligencia Turística (SIT). (n.d.) Retrieved from https://turismo.buenosaires.gob.ar/es/article/ noticia-la-ciudad-present\%C3\%B3-el-sistema-deinteligencia-tur\%C3\%ADstica

Santos, G. N. C. ; Inácio,J.B. (2018). Observatório do Turismo e Big Data: a importância da informação e da tecnologia no desenvolvimento de destinos turísticos e sustentáveis. Caminhos da Geografia (UFU. Online), 19, 286-299.

Siodmok, A. (2017, July 24). From best practice to next practice. Government UK. Retrieved from https:// openpolicy.blog.gov.uk/2017/07/24/from-best-practice-tonext-practice/

Sivarajah, U., Kamal, M. M., Irani, Z., Weerakkody, V. (2016). Critical analysis of Big Data challenges and analytical methods. Journal of Business Research, 70(1), 263-286. https:// doi.org/10.1016/j.jbusres.2016.08.001

UNWTO partners with Telefónica to promote tourism sector digitalization. (2019, April 30). Retrieved from http:// www2.unwto.org/press-release/2019-04-29/unwtopartners-telefonica-promote-tourism-sector-digitalization

Vale, S. (2013, June 27). Classification of Types of Big Data. Retrieved from https://statswiki.unece.org/display/bigdata/ Classification+of+Types+of+Big+Data

Vassakis K., Petrakis E., Kopanakis I. (2018). Big Data Analytics: Applications, Prospects and Challenges. Springer International Publishing AG. Mobile Big Data, Lecture Notes on Data Engineering and Communications Technologies 10, 320. doi: 10.1007/978-3-319-67925-9_1 
World Tourism Organization International Network of Sustainable Tourism Observatories. (n.d.) Retrieved from http:// insto.unwto.org/

WTTC. (2018). TRAVEL \& TOURISM ECONOMIC IMPACT 2018 BRAZIL. Retrieved from https://www.wttc.org/economicimpact/country-analysis/ 